\title{
PENGARUH PENAMBAHAN ABU SEKAM PADI TERHADAP STRUKTUR DAN SIFAT MEKANIK GEOPOLIMER BERBASIS FLY ASH
}

\author{
*Wahyuni \\ Universitas Negeri Makassar \\ wahyuniuni140797@gmail.com \\ Subaer \\ Universitas Negeri Makassar \\ subaer@unm.ac.id \\ Nurhayati \\ Universitas Negeri Makassar \\ nurhayati@unm.ac.id \\ *koresponden author
}

Abstrak - Telah dilakukan penelitian tentang geopolimer berbasis fly ash dengan penambahan abu sekam padi. Penelitian ini bertujuan untuk mengetahui struktur dan sifat mekanik geopolimer berbasis fly ash dengan penambahan abu sekam padi. Geopolimer berbasis fly ash dibuat dengan penambahan abu sekam padi $0 \%, 20 \%$ dan $40 \%$ menggunakan metode aktivasi alkali dan dipanaskan pada suhu $70^{\circ} \mathrm{C}$ selama 2 jam. Struktur mikro dari sampel diketahui dengan menggunakan teknik $X$ Ray Diffraction (XRD) dan menggunakan Scanning Electron Microscopy (SEM). Gugus fungsi dari sampel diperoleh berdasarkan pengujian Fourier Transform Infra Red (FTIR). Sifat mekanik seperti Kuat tekan dari sampel diuji menggunakan Testing Mechine. Massa jenis, porositas dan kuat lentur dilakukan pengukuran terhadap sampel. Hasil penelitian menunjukkan diperoleh fase trydimate yang tertinggi pada sampel Geo FA+ASP $(60+40) \%$. Hasil karakterisasi Scanning Elektron Microscopy (SEM) menunjukkan material penyusun sampel telah berikatan dengan baik walaupun sebagian kecil pertikel fly ash dan abu sekam padi masih terlihat dengan jelas. Gugus fungsi pembentuk geopolimer diperoleh pada stretching Si-O-Si dengan nilai gelombang antara $478-461 \mathrm{~cm}^{-1}$ dan $791-781 \mathrm{~cm}^{-1}$. Massa jenis tertinggi diperoleh pada sampel dengan penambahan $40 \%$ abu sekam padi dan porositas tertinggi diperoleh pada sampel tanpa penambahan abu sekam padi. Kuat tekan yang terbesar diperoleh dari sampel geopolimer berbasis fly ash tanpa penambahan abu sekam padi sedangkan kuat lentur tertingi diperoleh dari sampel geopolimer berbasis fly ash dengan penambahan abu sekam padi sebesar $40 \%$.

Kata Kunci : Geopolimer, Fly ash, Abu sekam padi, Struktur, Sifat Mekanik

Abstract - . Research on fly ash-based geopolymers with addition of rice husk ash. This recearch aims to determine the structure and mechanical properties of fly ash-based geopolymers with the addition of rice husk ash. Fly ash-based geopolymers was made with variations in addition of rice husk ash to $0 \%, 20 \%$ and $40 \%$ using an alkaline activation method and cured at $70{ }^{\circ} \mathrm{C}$ for 2 hours. The microstructure of sample is known by using X-Ray Diffraction (XRD) technique and using Scanning Electron Microscopy (SEM). The functional groups of samples are obtained based on Fourier Transform Infra Red (FTIR) testing. The compressive strength of the sample was tested using Testing Mechine and for density, porosity and flexural strength measurements was taken of sample and then included in calculation. The results showed highest trydimate phase was obtained in Geo FA + ASP sample $(60+40$ Scanning Electron Microscopy (SEM) characterization results showed that sample composition material hsve bonded properly well even though a small portion of the fly ash and rice husk ash is still clearly visible. Geopolymer forming function groups are, stretching $\mathrm{Si}-\mathrm{O}-\mathrm{Si}$ and $\mathrm{Si}-\mathrm{O}-\mathrm{A}$ found in the wave number band between $478-461 \mathrm{~cm}^{-1}$ dan $791-781 \mathrm{~cm}^{-1}$. Highest density was obtained in samples with the addition of $40 \%$ rice husk ash and highest porosity was obtained in samples without the addition of rice husk ash. The greatest compressive strength was obtained from fly ashbased geopolymer samples without the addition of rice husk ash while highest flexural strength was obtained from fly ash-based geopolymer samples with addition of $40 \%$ of rice husk ash.

Keywords : Geopolymer, Fly ash, Rice husk ash, Structur, Mechanical Properties 


\section{A. PENDAHULUAN}

Perkembangan penelitian di bidang geopolimer berkembang sangat cepat karena sifatnya yang unggul, meliputi kekuatan awal dan akhir yang tinggi, tahan panas dan api, stabilitas di bawah serangan kimia, daya rekat kuat pada permukaan logam dan non-logam (Sun dkk, 2018). Geopolimer merupakan material yang sangat banyak dibicarakan oleh para peneliti sebab proses produksinya yang memanfaatkan bahan-bahan alam yang ramah lingkungan. Geopolimer merupakan material anorganik alumina-silika yang disentesis melalui proses polimerisasi dari material dengan kandungan silika ( $\mathrm{Si}$ ) dan alumina ( $\mathrm{Al}$ ) yang cukup tinggi dan diperoleh dari alam atau dari material hasil sampingan industry (Manuahe dkk, 2014). Salah satu hasil sampingan industri yang dapat dijadikan sebagai prekursor atau bahan pengikat pada geopolimer ialah fly ash .

Fly ash dapat diperoleh dari residu pembakaran batu bara dan telah terbukti dapat digunakan untuk sintesis geopolimer. Fly ash dianggap menguntungkan karena partikelnya yang mudah bereaksi serta lebih halus dari pada slag (terak). Fly ash mengandung kalsium oksida, alumina dan silica (Arini dkk, 2013). Hal ini sesuai dengan penelitian yang telah dilakukan oleh Samadhi dkk, (2016) yang melaporkan bahwa komposisi oksida dari abu terbang diungguli oleh fase $\mathrm{SiO}_{2}$ dengan persentase $46,34 \%$ sedangkan hasil pengukuran untuk sifat mekanik yaitu kuat tekolimer berbahan dasar fly ash mencapai 92,52 $\mathrm{kg} / \mathrm{cm}^{2}$ pada suhu ruang dan pada suhu 60 mencapai $470,6 \mathrm{~kg} / \mathrm{cm}^{2}$.

Untuk meningkatkan struktur dan sifat mekanik dari fly ash diperlukan adanya material lain yang mengandung bahan silika dan alumina yang cukup tinggi untuk dapat memproduksi geopolimer yang lebih unggul, salah satu material yang memenuhi syarat tersebut dan dapat dipadukan dengan fly ash dalam pembuatan geopolimer ialah abu sekam padi.

Menurut data Badan Pusat Statistik (2017) memperlihatkan bahwa produksi padi pada tahun 2015 diperkirakan sebanyak 70846,5 juta ton. Sementara itu, hasil samping pengolahan padi serta limbahnya belum dimanfaatkan secara maksimal, seperti abu sekam padi. Abu sekam padi merupakan limbah yang diperoleh dari hasil pembakaran sekam padi yang menghasilkan sekitar $20 \%$ abu sekam dan mempunyai sifat pozzolan yang tinggi karena mengandung silika antara 92-95 \%, dengan kompszosisi silika yang sangat tinggi, memungkinkan untuk dijadikan bahan baku alternatif pembuatan beberapa senyawa berbasis silika seperti sodium silikat/silika gel. Abu sekam padi memiliki sifat yang porositasnya tinggi, ringan dan permukaan eksternal yang luas (Subaer, 2015). Ningsih dkk, (2012) menyatakan bahwa penambahan bahan additive berupa abu sekam padi dapat meningkatkan kuat tekan mortar. Hasil penelitian Hwang dkk, (2015) melaporkan penambahan 35\% abu sekam padi terhadap geopolimer berbahan dasar fly ash menunjukkan kuat tekan tertinggi 35,4 Mpa. Riswati dkk, (2017) menjelaskan bahwa hasil pengujian kuat tekan geopolimer yang dibuat dalam bentuk beton memiliki nlai maksimum 58,89 MPa pada komposisi dengan perbandingan fly ash : abu sekam padi sebesar (80: 20)\%. Penambahan abu sekam padi sekitar 35\%, memperbesar kekuatan tekan (compressive strenght) akibat tingginya persentase silika. Selain itu keunggulan lain dari abu sekam padi yakni bahannya 
mudah diperoleh dan relatif murah (Subaer, 2015). Berdasarkan latar belakang tersebut maka dikembangkan penelitian di bidang geopolimer yang berjudul "Pengaruh Penambahan Abu Sekam Padi Terhadap Struktur dan Sifat Mekanik Geopolimer Berbasis Fly ash".

\section{B. METODE}

Penelitian ini merupakan eksperimen murni yang dilaksanakan di laboratorium yang memanfaatkan limbah seperti fly ash sebagai bahan dasar produk geopolimer dan penambahan abu sekam padi terhadap struktur mikro dan sifat mekanik geopolimer. Penelitian ini dilakukan dengan menggunakan variasi dari sistem pada jenis sampel dengan menggnakan tiga perbandingan pada bahan dasar fly ash dan abu sekam padi yang berbeda yaitu perbandingan FA : $\quad$ ASP sebesar (100:0)\%; (80:20) dan (60:40)\%. Kedua bahan dasar tersebut disintesis dengan menggunakan metode aktivasi alkali. Proses yang dilakukan dalam mensintesis sampel yaitu pertama menyiapkan bahan dasar fly ash dan abu sekam padi sesuai perbandingan yang telah ditetapkan, kedua bahan tersebut dicampurkan hingga homogen. Kedua, menyiapkan larutan alkali yang terdiri atas $(\mathrm{NaOH}+$ $\mathrm{H}_{2} \mathrm{O}+\mathrm{Na}_{2} \mathrm{SiO}_{3}$ ). Ketiga, larutan alkali dituangkan ke dalam bahan dasar sedikit demi sedikit sambil diaduk hingga membentuk pasta geopolimer yang homogen. Keempat, pasta geopolimer dituangkan kedalam cetakan dan dikeringkan pada suhu $70^{\circ} \mathrm{C}$ selama 2 jam. Sampel yang telah dicuring tersebut dibiarkan pada cetakan selama 24 jam. Pada usia 28 hari kemudian dilepaskan dari cetakan untuk dilakukan berbagai pengujian seperti pengujian untuk struktur mikro meliputi, karakterisasi Scanning Electron Microscopy (SEM) untuk mengetahui keadaan morfologi dari sampel, karakterisasi X-Ray Diffraction (XRD) untuk mengetahui fase yang terbentu pada sampel. Untuk mengetahui gugus fungsi dari sampel dilakukan karakterisasi Fourier Transform Infra Red (FTIR) dan untuk sifat fisis dan mekaniknya dilakukan pengujian porositas, massa jenis, kuat tekan dan kuat lentur dari sampel.

\section{HASIL DAN PEMBAHASAN}

\section{A. Struktur Mikro Geopolimer}

1. Hasil Karakterisasi XRD Geopolimer berbasis fly ash dengan penambahan abu sekam padi.

Pada penelitian ini karakterisasi XRD digunakan untuk menganalisis fasa dan struktur kristal pada geopolimer berbasis fly ash dengan penambahan abu sekam padi menggunakan alat merk Rigaku MiniFlexII yang dilengkapi dengan software analyzer PDXL2. Hasil analisis dapat dilihat pada gambar 1. 


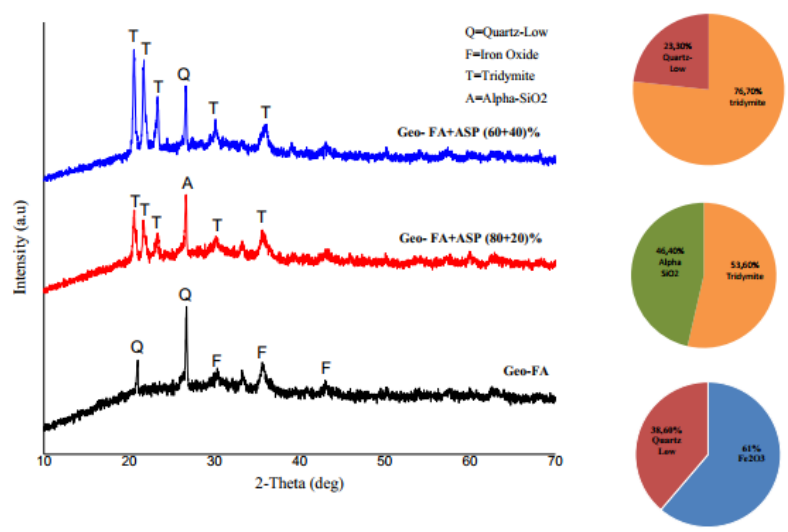

Gambar 1. Hasil karakterisasi XRD geopolimer berbasis fly ash dengan penambahan abu sekam padi

Gambar 1 merupakan hasil analisis XRD sampel geopolimer berbahan dasar fly ash tanpa penambahan abu sekam padi dan dengan penambahan abu sekam padi. Untuk geopolimer fly ash tanpa penambahan abu sekam padi atau diberi nama sampel Geo-FA diperoleh pola difraksi yang memperlihatkan dua fase yakni, QuartzLow sebesar 38,6\% dan Iron Oxide sebesar 61\%. Fase Quartz Low yang tinggi diperoleh pada rentang sudut $2 \theta=20,5-30^{\circ}$. Terdapat fase iron oxide yang cukup tinggi disebabkan pada proses sintesis yang dilakukan di laboratorium yang menyebabkan sampel terkontaminasi oleh senyawa yang lain. Jika dibandingkan dengan penambahan abu sekam padi pada sampel (Geo FA+ASP(80+20)\%) diperoleh pola difraksi dengan dua fase yakni, Tridymite sebesar 53,6\% dan Alpha-SiO 2 sebesar 46,4\%. Fase Tridymite yang tinggi diperoleh pada rentang sudut $2 \theta=20,5-30^{\circ}$ sedangkan pada sampel (Geo FA+ASP $\left.(60+40) \%\right)$ diperoleh pola difraksi dengan fase yang sama pada sampel sebelumnya (Geo FA+ASP(80+20)\%) yakni, Tridymite dan diperoleh fase yang sama juga dengan sampel (Geo-FA) yaitu fase Quartz-Low. Terjadi penambahan komposisi pada Tridymite yang cukup tinggi yaitu $76,7 \%$ yang diperoleh pada rentang sudut $2=10,5-20,5^{\circ}$ dan hal ini bersesuaian dengan penelitian sebelumnya oleh Riswati dkk, (2017) bahwa intensitas fase silica Tridymite meningkat seiring peningkatan abu sekam padi yang dipengaruhi oleh penambahan abu sekam padi yang cukup besar yaitu $40 \%$ dari bahan dasar.

2. Hasil karakterisasi SEM geopolimer berbasis fly ash dengan variasi penambahan abu sekam padi Untuk mengamati morfologi ikatan antara fly ash dan abu sekam padi dari sampel dilakukan karakterisasi SEM (Scanning Electron Microscopy). Citra SEM dari sampel geopolimer fly ash dengan variasi penambahan abu sekam padi sebesar $20 \%$ dan $40 \%$ ditunjukkan pada gambar 2 

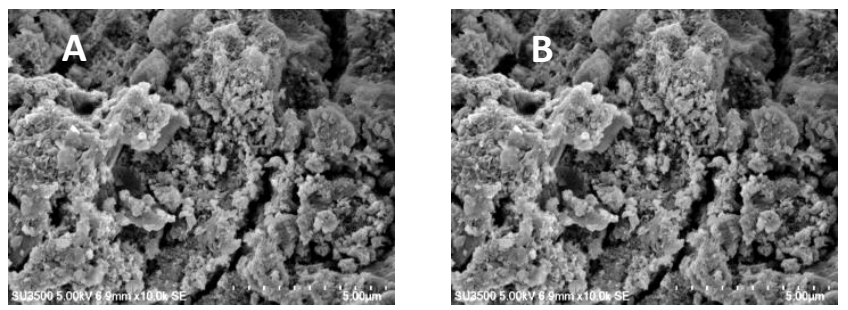

Gambar 2. Citra SEM Geopolimer berbasis Fly ash dengan penambahan abu sekam padi (A) $80 \%$ fly ash $+20 \%$ abu sekam padi (B) $60 \%$ fly ash $+40 \%$ abu sekam padi

Gambar 2 menunjukkan citra SEM dari sampel geopolimer dengan penambahan abu sekam padi sebesar $20 \%$ dan $40 \%$. Berdasarkan gambar tersebut citra SEM pada skala $5 \mu$ m menunjukkan reaksi antara fly ash dan abu sekam padi yang diaktivasi dengan larutan alkali, dapat dilihat bahwa material penyusunnya telah bereaksi dengan baik namun terdapat sebagian kecil partikel fly ash maupun abu sekam padi yang masih terlihat jelas. Partikel fly ash berbentuk seperti bola dan partikel abu sekam padi yang berwarna lebih terang, hal ini sesuai dengan Riswati dkk, (2017). Partikel yang tampak terang tersebut diakibatkan bahan abu sekam padi yang tidak tersebar secara merata dan hanya nampak pada bagian tertentu dari permukaan sampel, dikarenakan proses pembuatan sampel pasta geopolimer dengan penambahan abu sekam padi kurang homogen pada saat proses pencampuran bahan.

B. Hasil Gugus Fungsi (Karakterisasi FTIR Geopolimer berbasis Fly ash dengan variasi penambahan abu sekam padi)

Karakterisasi sampel menggunakan FTIR dilakukan untuk mengetahui gugus fungsi senyawa yang terbentuk dari sampel geopolimer berbasis fly ash dengan variasi penambahan abu sekam padi. Adapun hasil yang diperoleh ditunjukkan oleh gambar 3.

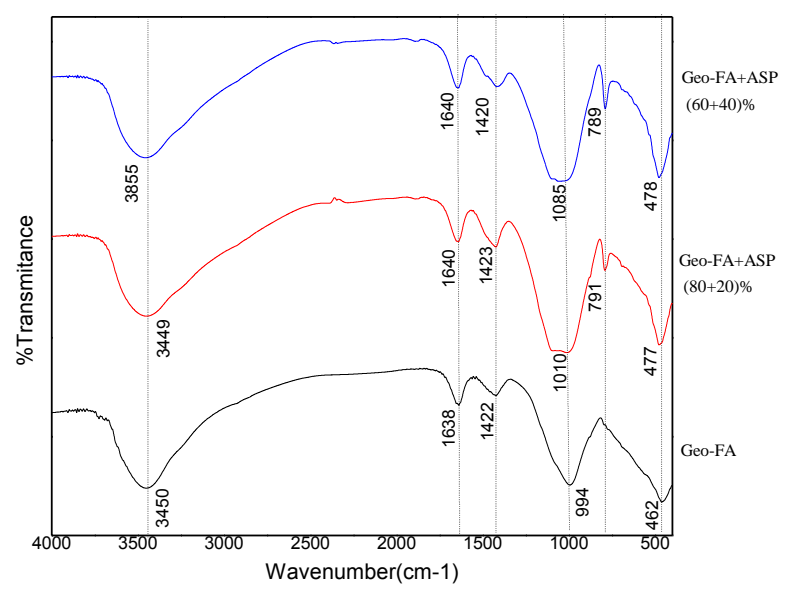

Gambar 3. Hasil karakterisasi FTIR sampel geopolimer berbasis fly ash dengan penambahan abu sekam padi

Gambar 3 menunjukkan spektrum IR (Infra Red) dari sampel geopolimer dengan 3 komposisi yang berbeda dan menunjukkan data bahwa pada bilangan gelombang $3855-3450 \mathrm{~cm}^{-1}$ terjadi stretching dari ikatan O-H. Pada bilangan gelombang 1640 - $1638 \mathrm{~cm}^{-1}$ terjadi bending dari ikatan O- 
H. Pada bilangan gelombang $1423-1420 \mathrm{~cm}^{-1}$ dikaitkan dengan stretching pada ikatan Al-O atau SiO. Pada bilangan gelombang sekitar 1085 - $994 \mathrm{~cm}^{-1}$ merupakan stretching pita Si-O/Al-O. Pada bilangan gelombang $791-781 \mathrm{~cm}^{-1}$ terjadi stertching quartz Si-O-Si dan untuk bilangan gelombang 478 - $462 \mathrm{~cm}^{-1}$ terjadi bending $\mathrm{O}-\mathrm{Si}-\mathrm{O}\left(\mathrm{SiO}_{4}\right)$. Bending dan stretching yang terjadi menunjukkan acuan utama terbentuknya jaringan atau rantai geopolimer, hal ini bersesuaian dengan penelitian yang telah dilakukan oleh Hwang dkk, (2015). Perbedaan penambahan abu sekam padi yang terbentuk di dalam jaringan geopolimer tampak tidak berpengaruh pada pita vibrasi gugus fungsional geopolimer karena nilai bilangan gelombang yang diperoleh mendekati antara sampel geopolimer berbasis fly ash maupun dengan variasi penambahan abu sekam padi.

C. Hasil Pengujian Sifat Fisis dan Mekanik Geopolimer berbasis Fly ash dengan penambahan Abu Sekam Padi

1. Pengukuran Porositas Geopolimer berbasis fly ash dengan variasi penambahan abu sekam padi Pengukuran porositas dilakukan untuk mengevaluasi kualitas fisik dari geopolimer .pengukuran porositas dilakukan dengan menggunakan metode Archimedes pada ketiga jenis sampel. Gambar 4 menunjukkan hasil pengukuran porositas dari sampel geopolimer berbasis fly ash dengan penambahan abu sekam padi. Pengukuran porositas dilakukan untuk mengetahui besar ukuran ruang kosong diantara suatu material. Gambar 4 menunjukkan hasil pengukuran porositas pada sampel geopolimer berbasis fly ash dengan penambahan abu sekam padi sebanyak 3 buah sampel. Dari ketiga sampel tersebut dapat dilihat nilai porositas yang diperoleh ialah semakin menurun seiring dengan penambahan abu sekam padi. Menurunnya nilai porositas dengan seiring penambahan abu sekam padi bersesuaian dengan Saraswathy dkk, (2007) yang disebabkan partikel abu sekam padi meningkatkan kepadatan partikel pada semen campuran yang menyebabkan berkurangnya volume pori sehingga porositas mengalami penurunan.

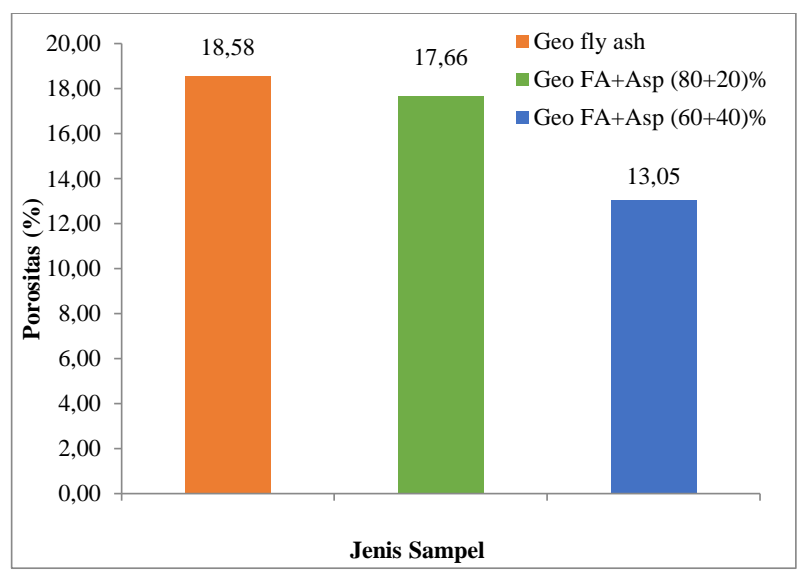

Gambar 4. Hasil pengukuran porositas dan massa jenis sampel geopolimer berbasis fly ash dengan penambahan abu sekam padi

2. Pengukuran massa jenis Geopolimer berbasis fly ash dengan variasi penambahan abu sekam padi

Pengukuran massa jenis dilakukan untuk mengetahui kerapatan suatu massa benda. .pengukuran massa jenis dilakukan dengan menggunakan metode Archimedes pada ketiga jenis 
sampel. Gambar 5 menunjukkan hasil pengukuran massa jenis dari sampel geopolimer berbasis fly ash dengan penambahan abu sekam padi.

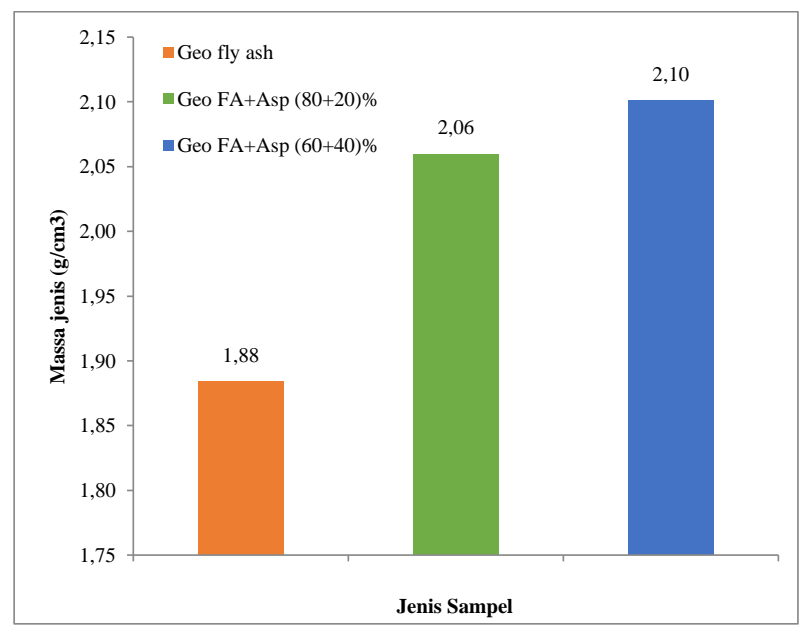

Gambar 5. Hasil pengukuran massa jenis sampel geopolimer berbasis fly ash dengan penambahan abu sekam padi

Gambar 5 menunjukkan hasil pengukuran massa jenis pada sampel geopolimer berbasis fly ash dengan penambahan abu sekam padi sebanyak 3 buah sampel. Dari ketiga sampel tersebut dapat dilihat nilai massa jenis yang diperoleh ialah semakin meningkat seiring dengan penambahan abu sekam padi, sehingga jika dibandingkan antara pengukuran porositas dan pengukuran massa jenis maka semakin menurun porositas maka semakin besar massa jenis yang diperoleh.

3. Pengujian Kuat Tekan Geopolimer berbasis fly ash dengan variasi penambahan abu sekam padi

Pengujian kuat tekan merupakan salah satu pengujian untuk menganalisis sifat mekanik sampel. Pengujian kuat tekan dilakukan untuk mengetahui kemampuan sampel menahan beban yang diberikan kepada sampel tersebut hingga mengalami kerusakan. Pengujian kuat tekan dilakukan di Laboratorium Teknik Sipil, Universitas Hasanuddin ketika sampel berusia 28 hari. Berikut merupakan grafik 6 hasil pengujian kuat tekan sampel geopolimer berbasis fly ash dengan penambahan abu sekam padi:

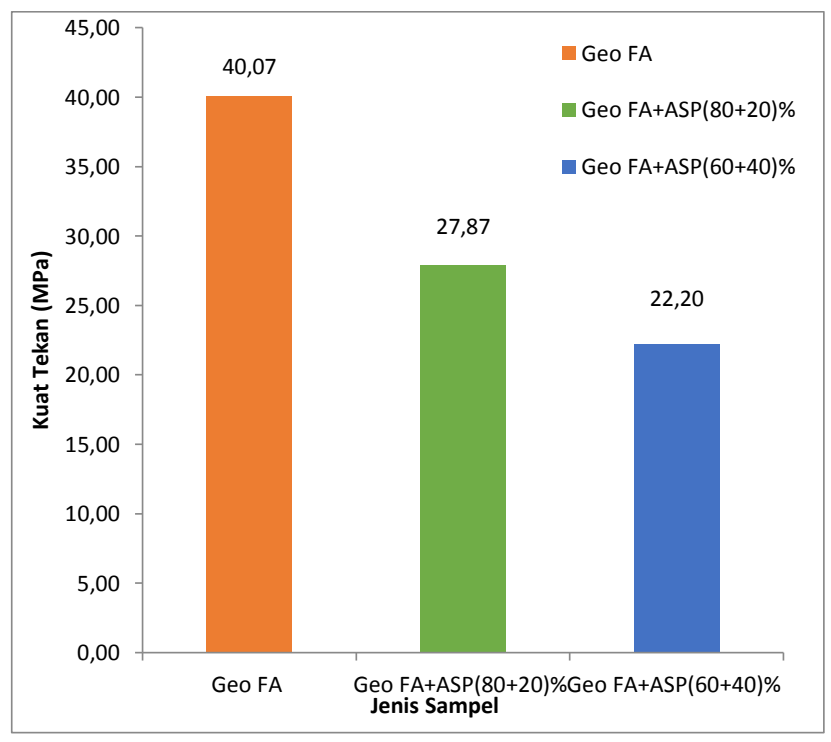


Gambar 6. Hasil pengujian kuat tekan sampel geopolimer berbasis fly ash dengan penambahan abu sekam padi

Gambar 6 menunjukkan gambar hasil pengujian kuat tekan dan diperoleh nilai kuat tekan tertinggi pada sampel Geo-FA, yakni sebesar 40,07 Mpa dan memperlihatkan bahwa nilai kuat tekan geopolimer yang didapatkan mengalami penurunan seiring dengan penambahan abu sekam padi. Hal ini terjadi karena pada saat dilakukan pemolesan untuk meratakan sampel dengan tujuan kuat tekan alat uji terdistribusi secara merata pada sampel. Akan tetapi hal tersebut membuat pori sampel terbuka dan memberikan pengaruh yang cukup signifikan terhadap sampel uji sehingga memperoleh kuat tekan yang rendah dan tidak mengalami kenaikan secara linear. Penurunan nilai kuat tekan seiring dengan penambahan abu sekam padi dapat menunjukkan bahwa, abu sekam padi kurang memberikan kontribusi terhadap geopolimer berbahan dasar fly ash (Zhu dkk, 2019).

4. Pengujian Kuat Lentur Geopolimer berbasis fly ash dengan variasi penambahan abu sekam padi

Pengujian kuat lentur sampel geopolimer dengan penambahan abu sekam padi dilakukan untuk mengetahui ketahanan sampel terhadap pembebanan pada tiga titik lentur (three bending point method). Sampel diuji setelah berusia 28 hari agar diperoleh nilai kuat lentur yang maksimum. Berikut merupakan grafik pada gambar 7 hasil pengujian kuat lentur sampel geopolimer berbasis fly ash dengan penambahan abu sekam padi:

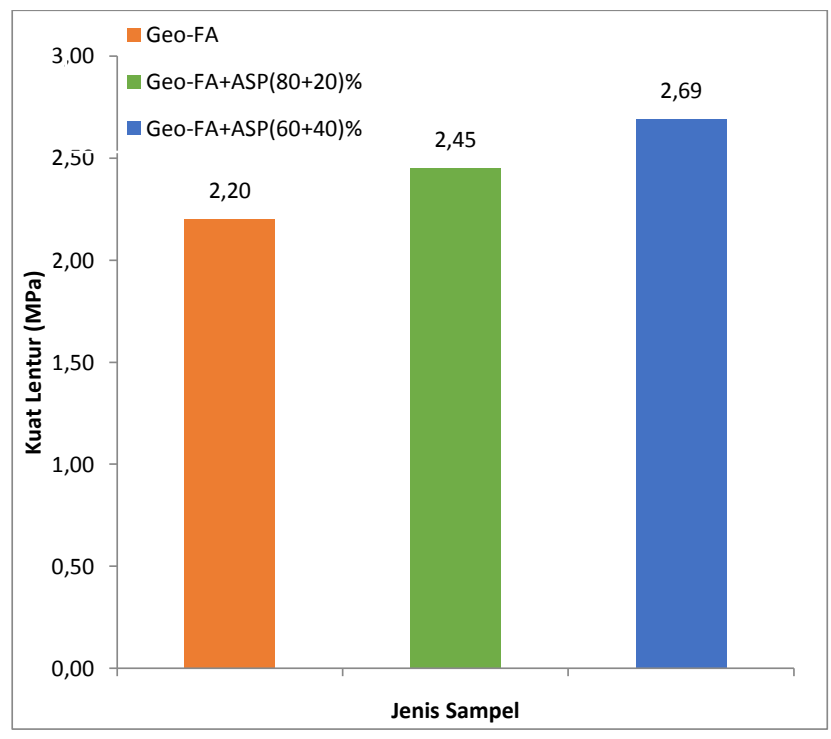

Gambar 7. Hasil pengujian kuat lentur sampel geopolimer berbasis fly ash dengan penambahan abu sekam padi

Gambar 7 menunjukkan hasil pengujian kuat lentur dan diperoleh nilai kuat lentur tertinggi pada sampel Geo-FA+ASP (60+40)\%, yakni sebesar 2,69 Mpa menunjukkan kualitas geopolimer yang paling baik sehingga dapat digunakan sebagai material struktural maupun material terapan yang berkualitas tinggi serta nilai kuat lentur yang diperoleh sampel mengalami peningkatan seiring dengan penambahan abu sekam padi. Hal ini bersesuaian dengan Oke dkk, (2019) yang ingin mengatahui pengaruh bahan dasar terhadap sifat mekanik beton geopolimer dan diperoleh kekuatan lentur tertinggi 
pada bahan abu sekam padi untuk setiap usia penguringannya. Hal ini diakibatkan oleh abu sekam padi yang memiliki jumlah alumina dan silika yang cukup tinggi.

\section{SIMPULAN}

Hasil analisis struktur mikro untuk karakterisasi XRD diperoleh fase untuk sampel Geo-FA yaitu,Quartz-Low sebesar 38,6\% dan Iron Oxide sebesar 61\%. Untuk sampel Geo-FA+ASP(80+20)\% diperoleh fase Tridymite sebesar 53,6\% dan Alpha-SiO2 sebesar 46,4\% serta untuk sampel GeoFA+ASP $(60+40) \%$ diperoleh fase Tridymite 76,7\% dan Quartz-Low 23,3\% sedangkan untuk karakterisasi SEM diperoleh morfologi untuk material penyusunnya telah bereaksi dengan baik namun terdapat sebagian kecil partikel fly ash dan abu sekam padi yang cukup terlihat jelas pada permukaan sampel dan untuk hasil analisis untuk karakterisasi FTIR menunjukkan gugus pembentuk geopolimer yakni, stretching Si-O-Si ditemukan pada bilangan gelombang antara sekitar $478-462 \mathrm{~cm}^{-1}$ dan 791 $781 \mathrm{~cm}^{-1}$. Kemudian untuk hasil pengukuran porositas dan massa jenis menunjukkan porositas mengalami penurunan seiring dengan penambahan abu sekam padi namun, mengalami peningkatan seiring dengan penambahan abu sekam padi dan untuk hasil pengujian kuat tekan menunjukkan nilai kuat tekan yang tertinggi diperoleh pada sampel Geo-FA atau tanpa penambahan abu sekam padi sebesar $|40 \pm 5|$ Mpa.

\section{DAFTAR RUJUKAN}

Achmad, D., \& A.G, H. (2012). Efek Perawatan Terhadap Karakteristik Beton Geopolymer. Jurusan Teknik Sipil, Politeknik Negeri Jakarta, 11(1), 79-86.

Afifah, K. N., Amalia, N., Syamsidar, D., \& Haris, A. (2017). The Influence of Synthesis Routes and Curing Time on the Mechanical and Microstructure Properties of Class C Fly ash Geopolymers, 020189. https://doi.org/10.1063/1.5002383

Arini, R. N., Triwulan, \& Ekaputri, J. J. (2013). Pasta Ringan Geopolimer Berbahan Dasar Lumpur Bakar Sidoarjo dan Fly ash Perbandingan 3:1 dengan Tambahan Aluminium Powder dan Serat Alam. Jurnal Teknik Pomits, 1(1), 1-5.

BPS, 2017. Produksi Padi, Jagung dan Kedelai (Angka Sementara Tahun 2015). In : No.26/03/Th.XIXed. s.I. :s.n.

Chithambaram, S. J., Kumar, S., \& Prasad, M. M. (2019). Thermo-mechanical characteristics of geopolymer mortar. Construction and Building Materials, 213(2019), 100-108. https://doi.org/10.1016/j.conbuildmat.2019.04.051

Ekaputri, J., \& Triwulan, T. (2013). Sodium Sebagai Aktivator Fly ash, Trass Dan Lumpur Sidoarjo Dalam Beton Geopolimer. Jurnal Teknik Sipil ITB, 20(1), 1-10. https://doi.org/10.5614/jts.2013.20.1.1

Hwang, C. L., \& Huynh, T. P. (2015). Effect of alkali-activator and rice husk ash content on strength development of fly ash and residual rice husk ash-based geopolymers. Construction and Building Materials, 101, 1-9. https://doi.org/10.1016/j.conbuildmat.2015.10.025

Khatimah, K., Muris, \& Irhamsyah, A. (2016). Pengaruh Penambahan Abu Sekam Padi Terhadap Sifat Mekanik dan Struktir Mikro Geopolimer Berbahan Dasar Lempung Laterite. Jurnal Sains Dan Pendidikan Fisika, 12(3), 316-323.

Manuahe, R., J, M. D., \& Windah, R. S. (2014). Kuat Tekan Beton Geopolymer Berbahan 
Dasar Abu Terbang (Fly ash). Sipil Statik, 2(6), 277-282.

Manuahe, R., Sumajouw, M. D. J., \& Windah, R. S. (2014). Kuat Tekan Beton Geopolymer Berbahan Dasar Abu Terbang (FLY ASH). Jurnal Sipil Statik, 2(6), 277-282.

Ningsih, T., Chairunnisa, R., \& Miskah, S. (2012). Pemanfaatan Bahan Additive Abu Sekam Padi Pada Cement Portland PT Semen Baturaja (Persero). Jurnal Teknik Kimia, 18(4), $59-67$.

Oke O, L., \& Ayeni I, S. (2019). Effects of Source Materials on Mechanical Properties of Geopolymer Concrete. American Journal of Engineering Research (AJER), 8(3), 146150 .

Riswati,B., Nurhayati, \& Suaber. (2017). Pengembangan beton geopolimer berbasis fly ash dan abu sekam padi untuk aplikasi struktural bawah laut. Jurnal Sains Dan Pendidikan Fisika (JSPF), 13(3), 287-291.

Samadhi, T. W., Hardika, R. C., \& Liustanto, R. (2016). Pengembangan Bahan Geopolimer Dengan Pemanfaatan Limbah Anorganik, 25(1), 18-28.

Saraswathy, V., \& Song, H. W. (2007). Corrosion performance of rice husk ash blended concrete. Construction and Building Materials, 21(8), 1779-1784. https://doi.org/10.1016/j.conbuildmat.2006.05.037

Subaer, 2015. Pengantar Fisika Geopolimer. Departemen Perguruan Tinggi, Jakarta

Sun, Z., \& Vollpracht, A. (2018). One year geopolymerisation of sodium silicate activated fly ash and metakaolin geopolymers. Cement and Concrete Composites. https://doi.org/10.1016/j.cemconcomp.2018.10.014

Zhu, H., Liang, G., Xu, J., Wu, Q., \& Zhai, M. (2019). Influence of rice husk ash on the waterproof properties of ultrafine fly ash based geopolymer. Construction and Building Materials, 208, 394-401. https://doi.org/10.1016/j.conbuildmat.2019.03.035 